\title{
Case Report \\ The Role of TRPM4 Gene Mutations in Causing Familial Progressive Cardiac Conduction Disease: A Further Contribution
}

\author{
Alberto Palladino ${ }^{1}$, Andrea Antonio Papa ${ }^{2}$, Roberta Petillo ${ }^{1} \oplus$, Marianna Scutifero ${ }^{1}$, Salvatore Morra ${ }^{1}$, \\ Luigia Passamano ${ }^{1}$, Vincenzo Nigro ${ }^{3}$ and Luisa Politano ${ }^{1, *}$ (])
}

1 Cardiomiology and Medical Genetics, University Hospital of Campania Luigi Vanvitelli, 80138 Naples, Italy; alberto.palladino@libero.it (A.P.); roberta.petillo@live.it (R.P.); scutifero.marianna59@libero.it (M.S.); salv.morra@gmail.com (S.M.); luigia.passamano@unicampania.it (L.P.)

2 Division of Cardiology, Department of Translational Medical Sciences, University of Campania "Luigi Vanvitelli", Monaldi Hospital, 80131 Naples, Italy; andreaantonio.papa@libero.it

3 Department of Precision Medicine, University of Campania Luigi Vanvitelli, 80138 Naples, Italy; vincenzo.nigro@unicampania.it

* Correspondence: luisa.politano@unicampania.it

check for

updates

Citation: Palladino, A.; Papa, A.A.; Petillo, R.; Scutifero, M.; Morra, S.; Passamano, L.; Nigro, V.; Politano, L. The Role of TRPM4 Gene Mutations in Causing Familial Progressive Cardiac Conduction Disease: A

Further Contribution. Genes 2022, 13, 258. https://doi.org/10.3390/ genes13020258

Academic Editor: Lars Allan Larsen

Received: 30 December 2021

Accepted: 26 January 2022

Published: 28 January 2022

Publisher's Note: MDPI stays neutral with regard to jurisdictional claims in published maps and institutional affiliations.

Copyright: (C) 2022 by the authors. Licensee MDPI, Basel, Switzerland. This article is an open access article distributed under the terms and conditions of the Creative Commons Attribution (CC BY) license (https:// creativecommons.org/licenses/by/ $4.0 /)$.

\begin{abstract}
Progressive cardiac conduction disease (PCCD) is a relatively common condition in young and elderly populations, related to rare mutations in several genes, including $S C N 5 A, S C N 1 B, L M N A$ and GJA5, TRPM4. Familial cases have also been reported. We describe a family with a large number of individuals necessitating pacemaker implantation, likely due to varying degrees of PCCD. The proband is a 47-year-old-patient, whose younger brother died at 25 years of unexplained sudden cardiac death. Three paternal uncles needed a pacemaker (PM) implantation between 40 and 65 years for unspecified causes. At the age of 42 , he was implanted with a PM for two episodes of syncope and the presence of complete atrioventricular block (AVB). NGS analysis revealed the missense variation c. $2351 \mathrm{G}>\mathrm{A}$, p.Gly844Asp in the exon 17 of the TRPM4 gene. This gene encodes the TRPM4 channel, a calcium-activated nonselective cation channel of the transient receptor potential melastatin (TRPM) ion channel family. Variations in TRPM4 have been shown to cause an increase in cell surface current density, which results in a gain of gene function. Our report broadens and supports the causative role of TRPM4 gene mutations in PCCD. Genetic screening and identification of the causal mutation are critical for risk stratification and family counselling.
\end{abstract}

Keywords: progressive cardiac conduction disease; atrio-ventricular block; right bundle branch block; Cardiac channelopathy

\section{Introduction}

Progressive cardiac conduction disorder (PCCD) is an inherited cardiac disease that may present as a primary electrical disease or in association with structural heart diseases, and often requires pacemaker (PM) implantation [1]. Because PM implantation improves survival [2], conduction disease poses an important health problem. Causal loci have been mapped for single-gene diseases involving atrioventricular conduction in isolation or associated with cardiomyopathy or skeletal myopathy; for a number of diseases, a causative gene has been identified [3].

The pathogenesis of the inherited PCCD in structurally normal hearts was linked to genetic variants in the ion channel genes SCN5A, SCN1B, SCN10A, TRPM4 and KCNK17 as well as in genes coding for cardiac connexin proteins, such as GJA5, associated with lone atrial fibrillation. [4]. LMNA mutations are also frequently reported in patients with life-threatening ventricular arrhythmias and significant cardiac conduction disorders, even if left ventricular ejection fraction is preserved [5]. Genetic forms of PCCD can often overlap or coexist with other inherited heart diseases or manifest in the context of multisystem syndromes. 
Other genes coding for cardiac transcription factors, such as NKX2.5 and TBX5, may be involved in the development of a cardiac conduction system and in morphogenesis of the heart [6]. Mutations in the two above mentioned genes may cause cardiac conduction disorders associated with various congenital heart defects.

However, despite the significant advances in the knowledge of the genetic architecture of PCCD and overlapping diseases, in a measurable fraction of cases, including in familial clustering of disease, investigations of known cardiac disease-associated genes fail to reveal the underlying substrate, suggesting that new causal genes are yet to be discovered.

A precise genetic diagnosis is essential for risk stratification and better selection of specific therapy; it also allows familiar cascade screening and appropriate genetic counseling. Cardiologists should be aware of the different phenotypes emerging from different gene-mutations and the potential risk of sudden cardiac death.

Isolated cardiac conduction blocks are not infrequent in the general population, prevalent in about $0.5 \%$ of children and occurring more in the 6 th decade and above, according to recent surveys [6].

Atrioventricular block (AVB) is the partial (1st or 2nd degree AVB) or complete (3rd degree AVB) interruption of the transmission of the electrical impulse from the atria to the ventricles (Figure 1). The most frequent causes are fibrosis and idiopathic sclerosis of the conduction system. Diagnosis is based on the ECG. Symptoms and therapy depend on the degree of blockage, but treatment, when needed, usually involves implantation of a pacemaker [7].

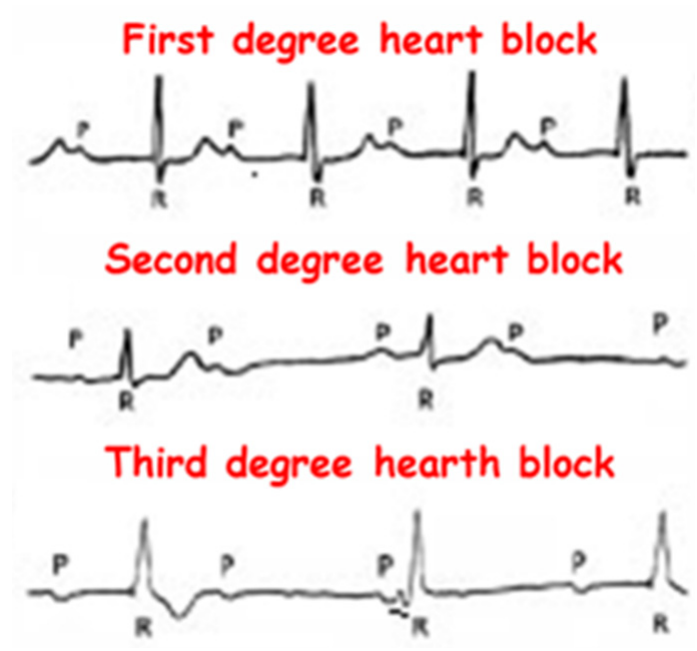

Figure 1. A schematic example of 1st, 2nd and 3rd degree AV block is shown as they appear on a 12-lead ECG.

In progressive familial heart block type I (PFHBI; also known as PFHBIB), an autosomal dominant inherited disease of the His-Purkinje system, disease progression is initially characterized by the occurrence of right bundle branch block (RBBB), followed by bifascicular block and finally by complete heart block (CHB) [8]. PFHBI was mapped to the kallikrein I [KLK1] locus, on chromosome 19q33 [9], but was also associated with mutations in ion channel genes SCN5A [10]. PFHBII differs clinically from PFHBI in that the $\mathrm{CHB}$ occurrence is consistent with an atrioventricular nodal level disease [9], rather than a ventricular conduction disease. Kruse et al [11], further refining the genetic interval for the PFHBI disease locus, showed that the missense mutation c.19G $\rightarrow \mathrm{A}$ in TRPM4 gene was the cause of blunted cardiac conduction in several branches of a large Afrikaner family they described.

Transient receptor potential channel melastatin 4 or TRPM4 is a Ca2+ activated nonspecific cationic channel, impermeable to $\mathrm{Ca} 2+$, which is part of the transient receptor potential channel (TRP) family [12,13]. TRPM4 in particular is expressed in cardiac cells of the conduction pathway and arterial and venous smooth muscle cells [14-18]. Genetic 
variants in the human gene TRPM4 have been associated with several cardiac conduction disorders. Hypertensive rats with cardiac hypertrophy have been shown to spontaneously over-express the cardiac TRPM4 channel [19]. Dominantly inherited mutations in the TRPM4 gene are associated with PFHBI and isolated cardiac conduction disease (ICCD), giving rise to the atrio-ventricular conduction block (AVB), right bundle branch block (RBBB), bradycardia, and Brugada syndrome. Demion et al. [19] investigated the role of the TRPM4 channel on whole cardiac function on a TRPM4 gene knock-out mouse (Trpm4-/-) model. Morpho-functional analysis revealed in these mice a left ventricular (LV) eccentric hypertrophy, with an increase in both wall thickness and chamber size in adult mice aged 32 weeks when compared to Trpm4+/+ littermate controls. Furthermore, Trpm4-/mice presented multilevel conduction blocks, as attested by PR and QRS lengthening in surface ECGs and confirmed by intra-cardiac exploration. As a nonselective monovalent cation channel, TRPM4 upregulation and activation enhance sodium entry, which leads to depolarization of the membrane potential. The membrane potential is critical in regulating calcium influx; calcium dysregulation is known to play an essential role in predisposing to tachy-arrhythmias and sudden cardiac death [20-22].

In the present study, we describe a family from South Italy with a large number of individuals necessitating pacemaker implantation likely due to varying degrees of PCCD, transmitted in an autosomal dominant manner and incomplete penetrance.

\section{Patients and Methods}

Family history. Parents unrelated, both with high blood pressure. On the paternal side, three uncles needed a pacemaker (PM) implant between the age of 40 and 65 years, for unspecified causes. The three uncles of the patient were dead at the time of the study and no clinical information was available for two of them. Only for the youngest uncle did the patient report that he was diagnosed with extreme bradycardia and high risk of cardiac arrest during a cardiologic check-up for dyspnea, and was immediately implanted. He was hypertensive.

The proband, currently 47, is the first of three siblings, all males, the last of whom died in his sleep at the age of 25 (Figure 2).

I
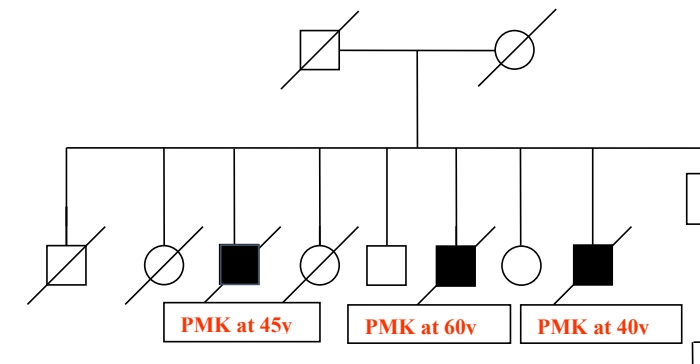

III
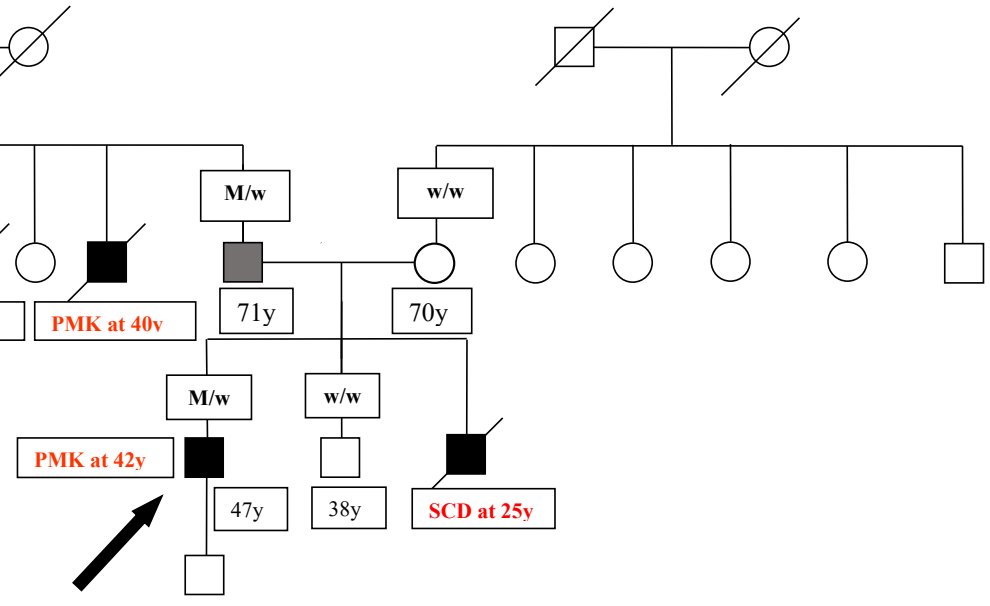
then as a coach. Two surgeries at 10 and 14 years, respectively, of appendectomy and rhinoseptoplasty were performed under general anesthesia, without complications.

At the age of 36, he presented a first episode of syncope, which has not been further investigated. After 6 years, a new episode of syncope required access to the local emergency room. On that occasion, he was diagnosed with complete atrio-ventricular block (AVB) on the ECG, for which he was implanted with a dual chamber pacemaker; he was discharged without cardiological treatment. A modest increase in serum creatinkinase (CK) levels was also observed (303 U/L vs. $170 \mathrm{U} / \mathrm{L})$.

Due to the concomitance of increased values serum CK, family history of sudden cardiac death and pacemaker implantation, the patient was advised to contact the Monaldi Hospital in Naples, and, from there, was sent to our service. The last ECG performed before admission to our service showed a first-degree AVB associated with a complete RBBB (Figure 3), while the echocardiogram showed a left ventricle ejection fraction (LVEF) of $45 \%$.

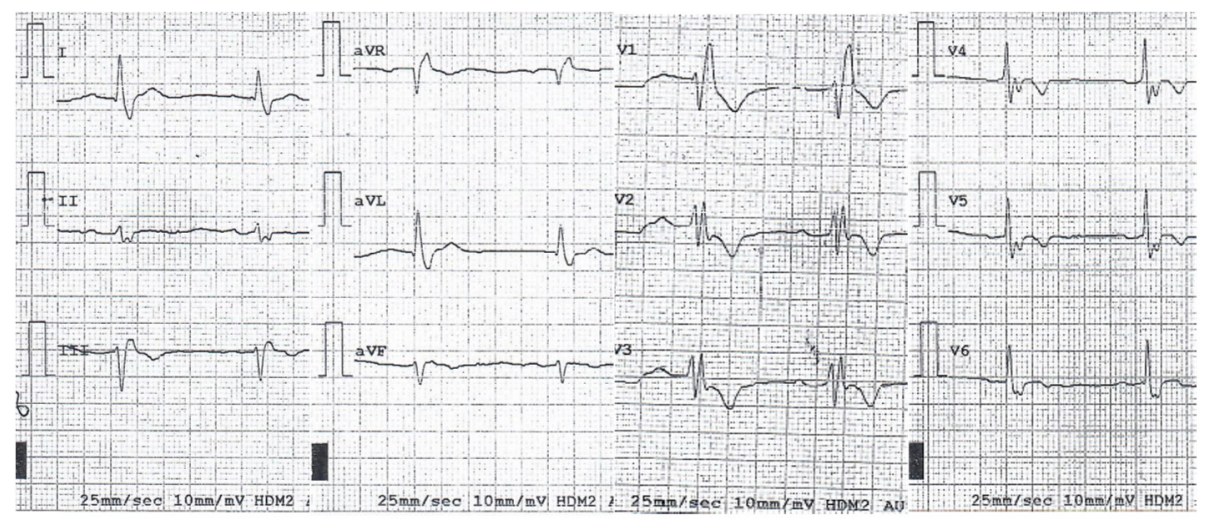

Figure 3. Proband's ECG tracing showing an incomplete right bundle branch block (RBBBi) associated with 1st degree atrio-ventricular block (AVB).

He started therapy with beta-blockers and ACE-inhibitors. Upon admission, the patient denied angor, palpitations and muscle symptoms, but complained of exertional dyspnea, even when walking.

Neuromuscular examination showed normal strength at girdle and distal lower limbs (deltoids, biceps and triceps brachialis 5/5, tibialis anterior e peroneal muscles 5/5), pes cavus, lumbar hyperlordosis, and normal deep tendon reflexes.

Cardiological examination revealed pure, rhythmic heart tones and a systolic murmur in the left fourth intercostal space. The ECG showed a PM rhythm, with a mean ventricular response of 56 beats/min. Dynamic ECG showed a PM rhythm with sporadic episodes of spontaneous rhythm, and repolarization anomalies when the PR interval was normal; during the PM rhythm, however, a first degree AVB appeared with a widened, electroinduced QRS interval (Figure 4).

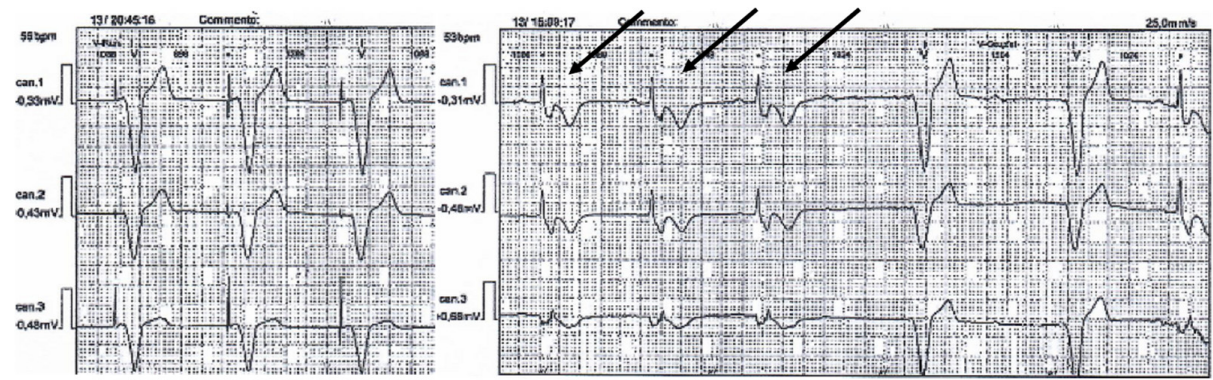

Figure 4. Proband's dynamic ECG tracing showing PM rhythm with sporadic episodes of spontaneous rhythm (arrows). 
Echocardiogram showed dilated hypokinetic cardiomyopathy, with reduced LVEF (35\%). Respiratory function was normal.

Pharmacological treatment was enhanced with the addition of diuretics (furosemide and potassium canrenoate), and folic acid for the detection of hyperhomocysteinemia.

At the last check-up, at age 47, the patient reported well-being, denied palpitations, exertional dyspnea or tachycardia. No muscular and respiratory symptoms. PM checks every six months.

The cardiological examination remained unchanged. ECG showed sinus rhythm, with first degree AVB (PR interval = $240 \mathrm{msec}$ ) and complete RBBB. Echocardiogram confirmed the presence of dilated cardiomyopathy, but LVEF was improved to $62 \%$. Right heart chambers were of normal size and kinetics.

The proband's father was also cardiologically evaluated. With the exception of arterial hypertension in drug treatment for years, no other pathology or specific symptomatology was reported. The ECG was normal (Figure 5).

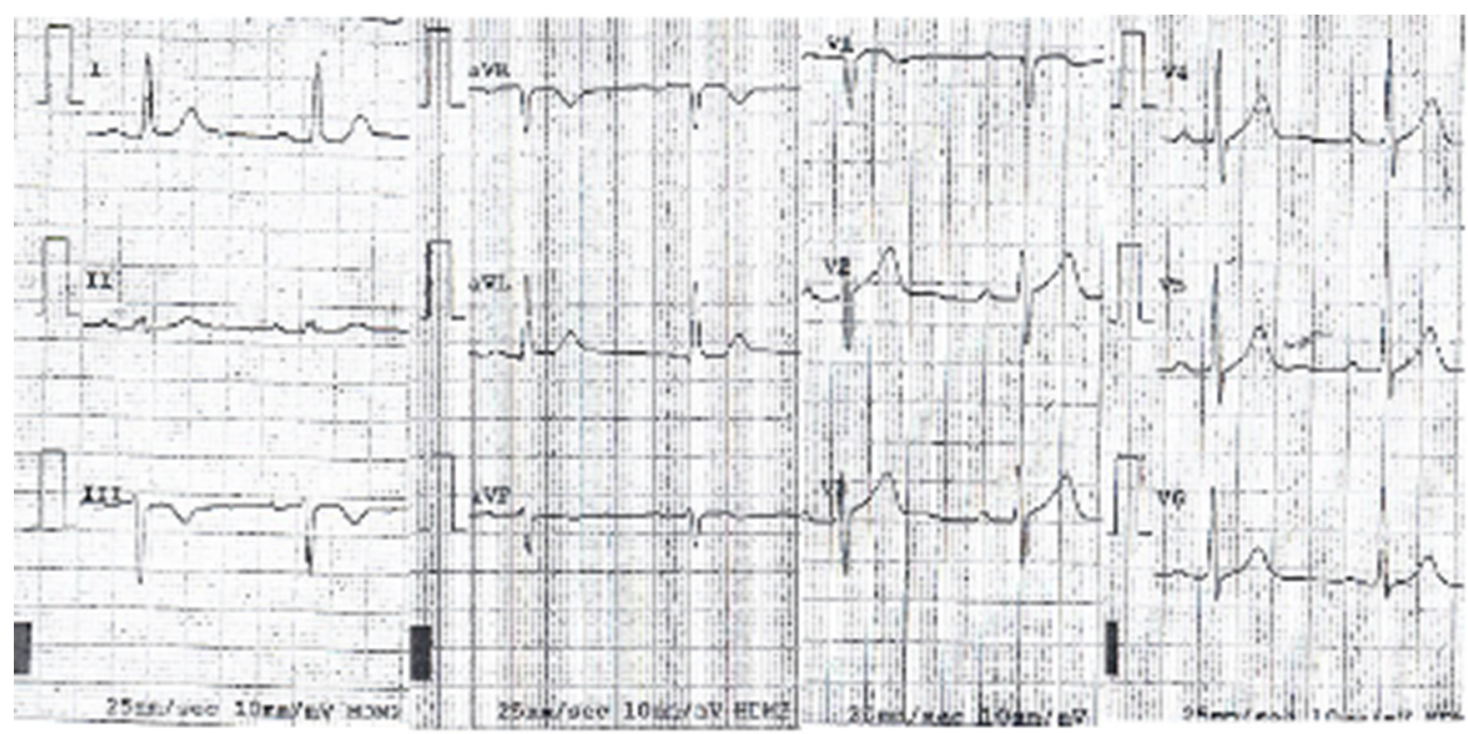

Figure 5. Proband's father ECG tracing showing a normal sinus rhythm, without signs of atrioventricular or bundle branch block.

A signed informed consent was obtained from the patient and his family prior to recording and blood drawing for DNA analysis. The study was conducted in accordance with the Declaration of Helsinki.

\section{Mutation Screening}

Genomic DNA was extracted from peripheral blood in the patient, his parents and the brother, by using standard procedures. For the mutation screening, the NGS technology was used. The panel included 2742 genes, all of which are involved in mendelian diseases, in muscular dystrophies and, in particular, those more frequently associated with cardiac conduction disturbances, arrhythmias and dilated cardiomyopathy, and enriched with Sure Select technology and Agilent Technology (Inherited Disease Panel). Parents and brother were also included in the NGS study.

\section{Results}

We first focused on screening for mutations in $L M N A$, desmin, myotilin and $L D B 3$ genes because, in our experience, mutations in these genes are seen more frequently in patients with cardiac conduction defects and increased $\mathrm{CK}$ values. These genes showed no mutations. NGS analysis discovered the single heterozygous mutation c. $2351 \mathrm{G}>\mathrm{A}$; p.Gly844Asp in exon 17 of the TRPM4 gene. The father also showed this mutation, while the mother and the unaffected brother did not. 


\section{Discussion}

In this report, a proband with 1st degree AVB associated with complete RBBB and a history of syncope was investigated by NGS analysis. The missense mutation TRPM4 c.2351G>A; p.Gly844Asp, which is located in the exon 17, was identified. This missense mutation was further confirmed in other family members by Sanger sequencing, suggesting that it co-segregates with the disease phenotype, and is likely responsible for PCCD in this family. The TRPM4 channel plays a crucial role in the cardiac conduction system. Immunohistochemistry results have shown that TRPM4 is highly enriched in ventricular cardiomyocytes and is highest in Purkinje fibers [23]. In previous studies, Mathar et al. demonstrated that Trpm 4 knock-out mice have a shortened ventricular action potential and an increased $\beta$-adrenergic-dependent ventricular systole [24]. In 2015, Jacobs et al. showed that deletion of the TRPM4 gene in mice improves survival and significantly enhances $\beta$-adrenergic cardiac reserve after inducing ischemic HF [25]. In 2009, Kruse et al. identified the first TRPM4 gene mutation in PFHBI patients [11]. Very recently, Dong et al. reported a novel TRPM4 mutation in a Chinese Family with atrioventricular block [26], supporting the idea that TRPM4 may act as a major gene predisposing to progressive familial heart block type I [27].

So far, 25 TRPM4 gene mutations have been reported in the Human Gene Mutation database at https://digitalinsights.qiagen.com/gene_mutation/database (accessed on 28 December 2021). Twenty-four of them are missense/nonsense mutations and one, a small insertion. Of these 25 mutations, 9 were associated to isolated cardiac conduction disease [11,27-29], $8+1$ (?) to Brugada syndrome [30,31], 3 to long QT syndrome [32], 2 to type 1 AVB [11,27] and 1 to unexpected sudden death in infancy [33] (Table 1).

Table 1. List of TRPM4 mutations so far reported in human gene mutation database.

\begin{tabular}{|c|c|c|c|c|}
\hline Phenotype & Codon Change & Amino Acid Change & Protein & Reference of First Description \\
\hline \multirow[t]{8}{*}{ Brugada Syndrome } & GGG-AGG & Gly-Arg & Gly555Arg & Liu, 2013 [30] \\
\hline & TTC-ATC & Phe-Ile & Phe773Ile & Liu, 2013 [30] \\
\hline & CCG-CGG & Pro-Arg & Pro779Arg & Liu, 2013 [30] \\
\hline & CAG-CGG & Gln-Arg & Gln854Arg & Liu, 2013 [30] \\
\hline & ACC-ATC & Thr-Ile & Thr873Ile & Liu, 2013 [30] \\
\hline & AAA-TAA & Lys-Term & Lys914Term & Liu, 2013 [30] \\
\hline & CTG-CCG & Leu-Pro & Leu1075Pro & Liu, 2013 [30] \\
\hline & CCG-CTG & Pro-Leu & Pro1204Leu & Liu, 2013 [30] \\
\hline Brugada Syndrome (?) & CGG-TGG & Arg-Trp & Arg144Trp & Liu, 2013 [30] \\
\hline \multirow[t]{9}{*}{ Cardiac Conduction Disease } & CAG-CAC & Gln-His & Gln131His & Stallmeyer, 2012 [29] \\
\hline & CGG-TGG & Arg-Trp & Arg164Trp & Liu, 2013 [30] \\
\hline & CAG-CGG & Gln-Arg & Gln293Arg & Stallmeyer, 2012 [29] \\
\hline & GCC-ACC & Ala-Thr & Ala432Thr & Liu, 2010 [28] \\
\hline & GGT-AGT & Gly-Ser & Gly582Ser & Stallmeyer, 2012 [29] \\
\hline & TAC-CAC & Tyr-His & Tyr790His & Stallmeyer, 2012 [29] \\
\hline & GGC-GAC & Gly-Asp & Gly844Asp & Liu, 2010 [28] \\
\hline & AAA-AGA & Lys-Arg & Lys914Arg & Stallmeyer, 2012 [29] \\
\hline & CCC-TCC & Pro-Ser & Pro970Ser & Stallmeyer, 2012 [29] \\
\hline \multirow[t]{2}{*}{ Heart Block Type 1} & GAG-AAG & Glu- Lys & Glu7Lys & Kruse, 2009 [11] \\
\hline & ATA- ACA & Ile-Thr & Ile376Thr & Daumy, 2016 [27] \\
\hline \multirow[t]{3}{*}{ Long QT Syndrome } & CTG-ATG & Val-Met & Val441Met & Hof, 2017 [32] \\
\hline & CGG-CCG & Arg-Pro & Arg499Pro & Hof, 2017 [32] \\
\hline & CGG-TGG & Arg-Trp & Arg499Trp & Hof, 2017 [32] \\
\hline $\begin{array}{l}\text { Sudden unexpected death in } \\
\text { infancy }\end{array}$ & TGG-TGA & Trp-Term & Trp5252Term & Hertz, 2016 [33] \\
\hline
\end{tabular}


The Gly844Asp variant found in our family had already been reported in multiple individuals, in association with cardiac conduction disorders [27-31]. The $2531 \mathrm{G}-\mathrm{A}$ transition in exon 17 resulting in Gly844Asp substitution occurs at a conserved residue within an intracellular sequence connecting the second and third transmembrane segments [28].

Liu et al [28] found this variation in several family members with incomplete RBBB or no block, consistent with incomplete penetrance. However, they did not find it in 300 ethnically matched control chromosomes. Furthermore, by functional analysis in HEK293 cells, Kruse et al. [11] demonstrated that current amplitudes were dramatically elevated for mutant versus wild type channels, despite no increase in $\mathrm{Ca} 2+$ affinity for the mutant channels compared to wild type. By quantitative analysis of transfected COS-7 cells, they showed that the gain of function was due to increased density of mutant channels at the cell surface, which, in turn, was related to impaired endocytosis and deregulation of SUMOylation.

The same variation was identified by Stallmeyer et al. [29] in two unrelated German patients with RBBB and left anterior hemiblock (LAHB). One patient was an asymptomatic 11-year-old boy with RBBB and LAHB but a normal heart rate; his 45-year-old mother, who had a normal electrocardiogram (ECG), also carried the mutation. The other patient was a 17-year-old boy who was compound heterozygous for Gly844Asp and a polymorphic in-frame deletion (2283-2294del, resulting in R762-G765del); his ECG showed a 'bizarre and obvious' RBBB and LAHB. His 45-year-old father, who also carried the mutation, had a normal ECG, as did his 44-year-old mother, who was a heterozygous carrier of the polymorphism.

However, the pathogenicity of this variation remains controversial, because several of these probands harbored additional cardiogenetic variants, and some of the relatives who were heterozygous for Gly844Asp were unaffected at the time of the examination [28,29,34-36]. Nevertheless, Gly844Asp is a non-conservative amino acid substitution, which can affect the secondary protein structure, as these residues differ in polarity, charge, size and/or other properties. This variant was described as probably damaging (0.945) with PPH-2 by Daumy et al. [27], in a homozygous state in a patient presenting with RBBB and left anterior hemiblock (LAHB) on ECG, and phenotypic AVB 2/1, 3/1. Furthermore, as previously indicated, functional studies suggest that the Gly844Asp variant causes a gain-of-function effect due to an elevated TRPM4 channel density at the cell surface [28]. Recently, an altered protein stability caused by TRPM4 cation channel mutations has been reported by Bianchi et al. [34]. Variants in the TRPM4 gene were associated with either gain- or loss-of-function of TRPM4 channels for a similar clinical phenotype. These findings plead in favor of the implication of multiple factors rather than simple TRPM4 gain- or loss-of-function to cause diseases [35,37].

However, our study, in combination with previously published papers, strongly support the prominent role of this cardiac TRP channel in this subtype of conduction disease. The clinical onset of conduction disturbances tends to occur at an early age among affected patients, as bundle branch blocks, and evolve in median/old age towards atrioventricular blocks. In this study, the presence of four cases implanted with a PM at varying age and early sudden cardiac death in a fourth family member suggest an important role of inheritance in disease severity. Furthermore, the observation that the proband's father, despite the mutation, does not have AVB, also suggests that additional genetic factors may determine the susceptibility to the disease.

Author Contributions: Conceptualization, L.P. (Luisa Politano); methodology, L.P. (Luisa Politano), V.N.; formal analysis of genetic data, V.N.; software, V.N.; validation, V.N.; investigation and data collection, A.P., A.A.P., R.P., M.S., S.M., L.P. (Luigia Passamano); data curation, L.P. (Luisa Politano); writing-original draft preparation, L.P. (Luisa Politano); writing-review and editing, L.P. (Luisa Politano); supervision, L.P. (Luisa Politano). All authors have read and agreed to the published version of the manuscript.

Funding: This research received no external funding. 
Institutional Review Board Statement: The study was conducted in accordance with the Declaration of Helsinki. The authorization of the Ethics Committee is not required for case reports when no pharmacological trials or procedures other than those of a normal routine are used, as in this case.

Informed Consent Statement: A signed informed consent was obtained from the patient prior to recording and blood drawing for DNA analysis and research publication.

Conflicts of Interest: The authors declare no conflict of interest.

\section{References}

1. Ector, H.; Rickards, A.F.; Kappenberger, L.; Vardas, P.; Oto, A.; Santini, M.; Sutton, R.; European Working Group on Cardiac Pacing. The registry of the European Working Group on Cardiac Pacing (EWGCP). A working group of the European Society of Cardiology. Europace 2000, 2, 251-255. [CrossRef] [PubMed]

2. $\quad$ Epstein, A.E.; Di Marco, J.P.; Ellenbogen, K.A.; Estes, N.A., 3rd; Freedman, R.A.; Gettes, L.S.; Gillinov, A.M.; Gregoratos, G.; Hammill, S.C.; Hayes, D.L.; et al. ACC/AHA/HRS 2008 Guidelines for Device-Based Therapy of Cardiac Rhythm Abnormalities: A report of the American College of Cardiology/American Heart Association Task Force on Practice Guidelines (Writing Committee to Revise the ACC/AHA/NASPE 2002 Guideline Update for Implantation of Cardiac Pacemakers and Antiarrhythmia Devices): Developed in collaboration with the American Association for Thoracic Surgery and Society of Thoracic Surgeons. Circulation 2008, 117, e350-e408. [CrossRef]

3. Benson, D.W. Genetics of atrioventricular conduction disease in humans. Anat. Rec. A Discov. Mol. Cell Evol. Biol. 2004 280, 934-939. [CrossRef] [PubMed]

4. Shi, H.F.; Yang, J.F.; Wang, Q.; Li, R.G.; Xu, Y.J.; Qu, X.K.; Fang, W.Y.; Liu, X.; Yang, Y.Q. Prevalence and spectrum of GJA5 mutations associated with lone atrial fibrillation. Mol. Med. Rep. 2013, 7, 767-774. [CrossRef] [PubMed]

5. Anselme, F.; Moubarak, G.; Savouré, A.; Godin, B.; Borz, B.; Drouin-Garraud, V.; Gay, A. Implantable cardioverter-defibrillators in lamin A/C mutation carriers with cardiac conduction disorders. Heart Rhythm 2013, 10, 1492-1498. [CrossRef]

6. Baruteau, A.E.; Probst, V.; Abriel, H. Inherited progressive cardiac conduction disorders. Curr. Opin. Cardiol. 2015, 30, 33-39. [CrossRef]

7. Da Silva, R.M.F.L.; de Souza Maciel, A. Conduction Disorders: The Value of Surface ECG. Curr. Cardiol. Rev. 2021, 17, 173-181. [CrossRef]

8. Brink, A.J.; Torrington, M. Progressive familial heart block-two types. S. Afr. Med. J. 1977, 52, 53-59.

9. Brink, P.A.; Ferreira, A.; Moolman, J.C.; Weymar, H.W.; van der Merwe, P.L.; Corfield, V.A. Gene for progressive familial heart block type I maps to chromosome 19q13. Circulation 1995, 91, 1633-1640. [CrossRef]

10. Schott, J.J.; Alshinawi, C.; Kyndt, F.; Probst, V.; Hoorntje, T.M.; Hulsbeek, M.; Wilde, A.A.; Escande, D.; Mannens, M.M.; Le Marec, H. Cardiac conduction defects associate with mutations in SCN5A. Nat. Genet. 1999, 23, 20-21. [CrossRef]

11. Kruse, M.; Schulze-Bahr, E.; Corfield, V.; Beckmann, A.; Stallmeyer, B.; Kurtbay, G.; Ohmert, I.; Schulze-Bahr, E.; Brink, P.; Pongs, O. Impaired endocytosis of the ion channel TRPM4 is associated with human progressive familial heart block type I. J. Clin. Investig. 2009, 119, 2737-2744. [CrossRef] [PubMed]

12. Launay, P.; Fleig, A.; Perraud, A.L.; Scharenberg, A.M.; Penner, R.; Kinet, J.P. TRPM4 is a Ca2+-activated nonselective cation channel mediating cell membrane depolarization. Cell 2002, 109, 397-407. [CrossRef]

13. Nilius, B.; Prenen, J.; Droogmans, G.; Voets, T.; Vennekens, R.; Freichel, M.; Wissenbach, U.; Flockerzi, V. Voltage dependence of the Ca2+-activated cation channel TRPM4. J. Biol. Chem. 2003, 278, 30813-30820. [CrossRef] [PubMed]

14. Abriel, H.; Syam, N.; Sottas, V.; Amarouch, M.Y.; Rougier, J.S. TRPM4 channels in the cardiovascular system: Physiology, pathophysiology, and pharmacology. Biochem. Pharmacol. 2012, 84, 873-881. [CrossRef]

15. Kruse, M.; Pongs, O. TRPM4 channels in the cardiovascular system. Curr. Opin. Pharmacol. 2014, 15, 68-73. [CrossRef]

16. Guinamard, R.; Demion, M.; Chatelier, A.; Bois, P. Calcium-activated nonselective cation channels in mammalian cardiomyocytes. Trends Cardiovasc. Med. 2006, 16, 245-250. [CrossRef]

17. Guinamard, R.; Chatelier, A.; Demion, M.; Potreau, D.; Patri, S.; Rahmati, M.; Bois, P. Functional characterization of a Ca(2+)activated non-selective cation channel in human atrial cardiomyocytes. J. Physiol. 2004, 558, 75-83. [CrossRef]

18. Gonzales, A.L.; Garcia, Z.I.; Amberg, G.C.; Earley, S. Pharmacological inhibition of TRPM4 hyperpolarizes vascular smooth muscle. Am. J. Physiol. Cell Physiol. 2010, 299, C1195-C1202. [CrossRef]

19. Demion, M.; Thireau, J.; Gueffier, M.; Finan, A.; Khoueiry, Z.; Cassan, C.; Serafini, N.; Aimond, F.; Granier, M.; Pasquié, J.-L.; et al. Trpm4 gene invalidation leads to cardiac hypertrophy and electrophysiological alterations. PLoS ONE 2014, 9, e115256. [CrossRef]

20. Gilbert, G.; Demydenko, K.; Dries, E.; Puertas, R.D.; Jin, X.; Sipido, K.; Roderick, H.L. Calcium Signaling in Cardiomyocyte Function. Cold Spring Harb. Perspect. Biol. 2020, 12, a035428. [CrossRef]

21. Wagner, S.; Maier, L.S.; Bers, D.M. Role of sodium and calcium dysregulation in tachy-arrhythmias in sudden cardiac death Circ. Res. 2015, 116, 1956-1970. [CrossRef] [PubMed]

22. Fong, S.P.T.; Agrawal, S.; Gong, M.; Zhao, J. Modulated Calcium Homeostasis and Release Events Under Atrial Fibrillation and Its Risk Factors: A Meta-Analysis. Front. Cardiovasc. Med. 2021, 8, 662914. [CrossRef] [PubMed] 
23. Guinamard, R.; Bouvagnet, P.; Hof, T.; Liu, H.; Simard, C.; Sallé, L. TRPM4 in cardiac electrical activity. Cardiovasc. Res. 2015, 108, 21-30. [CrossRef] [PubMed]

24. Mathar, I.; Jacobs, G.; Kecskes, M.; Menigoz, A.; Philippaert, K.; Vennekens, R. TRPM4. Handb. Exp. Pharmacol. 2014, 222, 461-487. [CrossRef]

25. Jacobs, G.; Oosterlinck, W.; Dresselaers, T.; Geenens, R.; Kerselaers, S.; Himmelreich, U.; Herijgers, P.; Vennekens, R. Enhanced?adrenergic cardiac reserve in Trpm4?/? mice with ischaemic heart failure. Cardiovasc. Res. 2015, 105, 330-339. [CrossRef]

26. Dong, Y.; Du, R.; Fan, L.L.; Jin, J.Y.; Huang, H.; Chen, Y.Q.; Bi, D.D.; Xiang, R. Whole-Exome Sequencing Identifies a Novel TRPM4 Mutation in a Chinese Family with Atrioventricular Block. Biomed. Res. Int. 2021, 2021, 9247541. [CrossRef]

27. Daumy, X.; Amarouch, M.Y.; Lindenbaum, P.; Bonnaud, S.; Charpentier, E.; Bianchi, B.; Nafzger, S.; Baron, E.; Fouchard, S.; Thollet, A.; et al. Targeted resequencing identifies TRPM4 as a major gene predisposing to progressive familial heart block type I. Int. J. Cardiol. 2016, 207, 349-358. [CrossRef]

28. Liu, H.; El Zein, L.; Kruse, M.; Guinamard, R.; Beckmann, A.; Bozio, A.; Kurtbay, G.; Mégarbané, A.; Ohmert, I.; Blaysat, G.; et al. Gain-of-function mutations in TRPM4 cause autosomal dominant isolated cardiac conduction disease. Circ. Cardiovasc. Genet. 2010, 3, 374-385. [CrossRef]

29. Stallmeyer, B.; Zumhagen, S.; Denjoy, I.; Duthoit, G.; Hébert, J.L.; Ferrer, X.; Maugenre, S.; Schmitz, W.; Kirchhefer, U.; SchulzeBahr, E.; et al. Mutational spectrum in the $\mathrm{Ca}(2+)$-activated cation channel gene TRPM4 in patients with cardiac conductance disturbances. Hum. Mutat. 2012, 33, 109-117. [CrossRef]

30. Liu, H.; Chatel, S.; Simard, C.; Syam, N.; Salle, L.; Probst, V.; Morel, J.; Millat, G.; Lopez, M.; Abriel, H.; et al. Molecular genetics and functional anomalies in a series of 248 Brugada cases with 11 mutations in the TRPM4 channel. PLoS ONE 2013, 8, e54131. [CrossRef]

31. Janin, A.; Bessière, F.; Georgescu, T.; Chanavat, V.; Chevalier, P.; Millat, G. TRPM4 mutations to cause autosomal recessive and not autosomal dominant Brugada type 1 syndrome. Eur. J. Med. Genet. 2019, 62, 103527. [CrossRef] [PubMed]

32. Hof, T.; Liu, H.; Sallé, L.; Schott, J.J.; Ducreux, C.; Millat, G.; Chevalier, P.; Probst, V.; Guinamard, R.; Bouvagnet, P. TRPM4 non-selective cation channel variants in long QT syndrome. BMC Med. Genet. 2017, 18, 31. [CrossRef] [PubMed]

33. Hertz, C.L.; Christiansen, S.L.; Larsen, M.K.; Dahl, M.; Ferrero-Miliani, L.; Weeke, P.E.; Pedersen, O.; Hansen, T.; Grarup, N.; Ottesen, G.L.; et al. Genetic investigations of sudden unexpected deaths in infancy using next-generation sequencing of 100 genes associated with cardiac diseases. Eur. J. Hum. Genet. 2016, 24, 817-822. [CrossRef] [PubMed]

34. Bianchi, B.; Ozhathil, L.C.; Medeiros-Domingo, A.; Gollob, M.H.; Abriel, H. Four TRPM4 Cation Channel Mutations Found in Cardiac Conduction Diseases Lead to Altered Protein Stability. Front Physiol. 2018, 9, 177. [CrossRef] [PubMed]

35. Amarouch, M.Y.; El Hilaly, J. Inherited Cardiac Arrhythmia Syndromes: Focus on Molecular Mechanisms Underlying TRPM4 Channelopathies. Cardiovasc. Ther. 2020, 2020, 6615038. [CrossRef]

36. Celestino-Soper, P.B.; Doytchinova, A.; Steiner, H.A.; Uradu, A.; Lynnes, T.C.; Groh, W.J.; Miller, J.M.; Lin, H.; Gao, H.; Wang, Z.; et al. Evaluation of the Genetic Basis of Familial Aggregation of Pacemaker Implantation by a Large Next Generation Sequencing Panel. PLoS ONE 2015, 10, e0143588. [CrossRef]

37. Syam, N.; Chatel, S.; Ozhathil, L.C.; Sottas, V.; Rougier, J.S.; Baruteau, A.; Baron, E.; Amarouch, M.Y.; Daumy, X.; Probst, V.; et al. Variants of Transient Receptor Potential Melastatin Member 4 in Childhood Atrioventricular Block. J. Am. Heart Assoc. 2016, 5, e001625. [CrossRef] 